"Fauna and Flora of the Gulf of Naples," either already published (Dr. Giesbrecht's monograph is the nineteenth volume published) or in preparation may convince also those who may still be doubtful in this regard.

Later, and in another article, I may be permitted to discuss some questions regarding another great publication of the Zoological Station, the Zoologischer Jahresbericht, a discussion which will touch some of the most vital questions of scientific organisation.

ANTON DOHRN.

\section{BRITISH ASSOCIATION, NOTTINGHAM} MEETING.

FURTHER information has been forwarded since the last issue of NATURE from Presidents and Recorders of Sections, of which the following statement is a summary :-

In Section B the following papers are promised, in addition to those already mentioned:- "The Action of Permanganate on Sulphites and Thiosulphates," by G. E. Brown and W. W. J. Nicol; "The Relation existing between Chromium and Certain Organic Acids, and some New Chromoxalates," and on "The Action of Phosphorus Pentachloride on Urethanes," by Emil A. Werner; "The Occurrence of Cyanonitride of Titanium in Ferromanganese," by T. W. Hogg ; "Hydrogen Flame-cap Measurements, and the Adaptation of the Hydrogen-flame to the Miners' Safety-lamp," by Prof. Frank Clowes. A general statement of the arrangement of work in this Section appeared in last week's NATURE. The only probable alteration is the shifting of $M$. Moissan's demonstration to Friday, September 15, and of the Bacteriological discussion to Monday, 18.

An interesting paper is promised to Section $\mathrm{E}$ by $\mathrm{Mr}$. Cope Whitehouse, a distinguished American citizen of New York and Cairo.

The presidential address in Section F, on "The Reaction in favour of the Classical Political Economy " will be mainly inspired by the idea that the principles and methods of the classical and orthodox economists have only been modified and supplemented, not displaced, by recent writers ; and that both theoretically and practically there are signs of a reaction in favour of the older doctrines as against socialism.

The probable arrangement of work in Section $\mathrm{H}$ is as follows:-On Thursday, September I4, the President's address will be delivered, and a few papers on physical anthropology will be read. On Friday, I 5, Dr. Hans Hildebrand, Royal Antiquary of Sweden, will read his paper on "Anglo-Saxon Remains, and the Coeval Ones in Scandinavia," and this will be followed by archæulogical papers. On Monday, 18, various papers will be taken. On Tuesday, 19, Dr. Munro will describe "The Structure of Lake Dwellings," and Mr. Arthur Bulleid will give an account of " The Recently Discovered Lake or Marsh Village near Glastonbury."

Papers which have not been already mentioned in Section H are-" Anthropometric Work in Schools," by Prof. Windle; "The Prehistoric Evolution of the Theories of Punishment, Revenge and Atonement," by Rev. G. Hartwell Jones ; "Pin-wells and Rag-bushes," by Mr. Hartland ; and "The Tribes of the Congo," by Mr. Herbert Ward.

The Local Secretaries wish to announce that the local programme and the list of hotels and lodgings are ready for issue, and may be obtained by application at the British Association Office, Guildhall, Nottingham, until September 9; after that, application should be made at the Reception Room, Mechanics' Institution. It may also be stated that the local committee has engaged the Theatre Royal for Wednesday night, September 20, when Mr. Wilson Barrett's Company will give the new play "Pharaoh." It is hoped that members will avail themselves of the invitation extended to them for this entertainment, and that it will induce them to remain in Nottingham, and take advantage of the excursions arranged for the following day. Other items worthy of mention are a special concert, which will be given by the Nottingham Sacred Harmonic Society on the Saturday night; and a garden-party, given by Mr. J. W. Leavers, in whose grounds some of the old rock-divellings of Nottingham are to be seen. Geologists and naturalists will be interested to know that amongst the special local literature will be a little book entitlec "Contributions to the Geology and Natural History of Nottinghamshire," which has been edited by Mr. J. W. Carr, M.A., with the assistance of local specialists.

FRANK ClOWES.

\section{SCIENCE IN THE MAGAZINES.}

SCIENCE makes a poor show in the September magazines. There are, however, one or two important articles which claim attention. in the Contemporary Review Prof. A. Weismann writes on "The All-Sufficiency of Natural Selection," his essay being an answer to two articles by Mr. Herbert Spencer directed against Prof. Weismann's views on heredity and natural selection. The essay is not merely controversial, but also a clear explanation of Weismannism. The following is the concluding paragraph :-

I hold it to be demonstrated that all hereditary adaptation rests on natural selection, and that natural selection is the one great principle that enables organisms to conform, to a certain high degree, to their varying conditions, by constructing new adaptations out of old ones. It is not merely an accessory principle, which only comes into operation when the assumed transmission of functional variations fails; but it is the chief principle in the variation of organisms, and compared to it, the primary variation which is due to the direct action of external influences on the germ-plasm, is of very secondary im portance. For, as I previously said, the organism is composed of adaptations, some of which are of recent date, some are older, some very old; but the influence of primary variations on the physiognomy of species has been slight and of subordinate importance. Therefore I hold the discovery of natural selection to be one of the most fundamental ever made in the field of biology, and one that is alone sufficient to immortalise the names of Charles Darwin and Alfred Wallace. When my opponents set me down as an ultra-Darwinist, who takes a onesided and exaggerated view of the principle discovered by the great naturalist, perhaps that may make an impression on some of the timid souls who always act on the supposition that the juste-milieu is proper; but it seems to me that it is never possible to say a priori how far-reaching a principle of explanation is: it must be tried first ; and to have made such a trial has been my offence or my merit. Only very gradually have I learned the full scope of the principle of selection; and certainly I have been led beyond Darwin's conclusions. Progress in science usually involves a struggle against deep-rooted prejudices: such was the belief in the transmission of acquired characters; and it is only now that it has fortunately been overcome that the full significance of natural selection can be discerned. Now, for the first time, consummation of the principle is possible; and so my work has not been to exaggerate, but to complete.

Two articles of scientific interest appear in the Fortnightly Review. One, by Mr. W. Bevan Lewis, on "The Origin of Crime," deals with drunkenness, insanity, epilepsy, and similar affections in their mutual relationship to crime ; in the second, entitled "The Climbing of High Mountains," Mr. W. M. Conway enthusiastically supports mountaineering in unexplored regions. Ordinary official surveys do not supply the detailed information with regard t.) buttress and fold in which resides the clue of mountain structure. It is for mountaineers to make up the deficiency.

NO. I 245 , VOL. 487 